Ann. Génét. Sél. anim., I970, 2 (4), 457-469.

LITERATURE REVIEW

\title{
CYTOTAXONOMY AND CHROMOSOMAL EVOLUTION OF THE BATS \\ (MAMMALIA-CHIROPTERA)
}

\author{
Alan R. RUSHTON \\ Biology Department, \\ Earlham College \\ Richmond, Indiana U.S.A. 47374
}

\section{SUMMARY}

An extensive literature search has compiled diploid chromosome numbers for 110 species of bats. Karyotypes for 87 of these have been reported and are used as the basis for defining tentative cytological relationships within the families Pteropodidae, Rhinopomatidae, Phyllostomatidae, Desmodontidae, Rhinolophidae, and Vespertilionidae. Before more definitive intrafamilial relationships can be established, karyotypes from more species of the order Chiroptera must be reported.

The earliest fossil remains from Eocene deposits in Wyoming and Germany reveal almost modern bats with well-developed webbed wings $(1,21,32)$. By the end of the Eocene and the first part of the Oligocene many of the modern families of bats had appeared and are represented in fossils from these periods (50).

The ancient line from which the bats developed is believed to be an extinct small arboreal insectivore. There is no fossil evidence for phylogeny and any theories on the origin of the Chiroptera must rest on speculation (8).

Both regional gene duplication and polyploidization have played important roles in progressively incrasing the amount of nuclear D.N.A. in lower vertebrates $(5,33,35,40,49)$. Establishment of the chromosomal sex-determining mechanism in higher vertebrates has tended to stabilize each genome with its own particular amount of D.N.A. and hence number of gene loci. Diploid cells of eutherians, monotremes, marsupials, and certain birds and reptiles all have about the same amount of nuclear D.N.A.: $7.0 \times 10^{-9} \mathrm{mg}(39)$.

The karyotypic evolution of the higher vertebrates from their ancestors has not been due to polyploidization, but to mutations at existing gene loci with accompanying rearrangements 
of the chromosomes. The purpose of this paper is to review the literature on bat chromosomes and present some preliminary conclusions as to chiropteran phylogeny based on chromosomal evidence.

The first studies of bat chromosomes were performed using gonadal material $(7,24,31)$. Most recent reports of bat karyotypes have been based on chromosomes isolated from bone marrow using techniques modified from that of TJio and Whang (52). Other workers prefer to use lung, spleen, liver, gonad, or fibroblast cultures as the tissue source for the chromosomes $(e g ., 16)$.

According to classical taxonomic methodology there are seventeen families in Chiroptera. Diploid numbers flom at least one species in twelve families have been reported (Table 1). Of these families, karyotypes from enough species from the families Pteropodidae, Rhinopomatidae, Desmodontidae, Phyllostomatidae, Rhinolophidae, and Vespertilionidae have been published to warrant the attempt to begin to define intra-ordinal relationships on the basis of chromosome number and morphology.

\section{FAMILIES PTEROPODIDAE AND RHINOPOMATIDAE}

The suborder Megachiroptera is composed of the family Pteropodidae which has about 39 recognized genera. One of the most ancient families of Microchiroptera is believed to be Rhinopomatidae (23). The karyotype of Rousettus leschenaulti (Pteropodidae), Rhinopoma hardwickii (Rhinopomatidae), and several species of Pteropus (Pteropodidae) are quite similar in both diploid number and F.N. (The fundamental number (F.N.) is here defined to be the number of chromosomal arms among the autosomes of the diploid karyotype. Acrocentrics and telocentrics have one arm: subtelocentrics, metacentrics, and submetacentrics have two arms. Minute chromosomes whose morphology (annot be accurately determined are counted as acrocentrics). In both families the $\mathrm{X}$ chromosomes are the same relative size and differ only in centromere position. The acrocentric $\mathrm{Y}$ is present in both. The major differences between the karyotypes can be explained by pericentric inversions (47).

All Microchiroptera echolocate, but only Rousettus in Megachiroptera does so (23). On the basis of these and other similarities in skeleton and fetal membranes, Rhinopomatidae may be more closely related to Pteropodidae and especially to Rousettus than to other Microchiroptera. The rhinopomatid bats may represent species which early diverged from the ancestral line to form the larger, more modern suborder Microchiroptera (47).

\section{FAMILY PHYLLOSTOMATIDAE}

Considerable study has been devoted to Macrotus waterhousii. Specimens collected in Mexico (subspecies mexicanus) have the same F.N. but different diploid number and karyotype when compared to specimens from Arizona and California in the United States (subspecies californicus). The direction of this intraspecific change cannot be determined, but centric fusion of six telocentric pairs in species with fourteen such pairs would not alter the F.N. and would increase the number of non-telocentric chromosomes by three pairs and reduce the diploid number from 46 to 40 . The change may have been from lower to higher number of biarmed chromosomes $(36,37)$.

Subfamilies Glossophaginae, Carollinae, and Stenoderminae are significant because they contain genera which possess the so-called $\mathrm{XX} / \mathrm{XY} \mathrm{Y}_{1} \mathrm{Y}_{2}$ system of sex chromosomes. Robertsonian fusion of the original $X$ with an autosome could have reduced the $F$.N. by two in both sexes, and the diploid number by two in the female but by only one in the male. The result of this translocation process would be a new $X$ composed of the original $X$ and fused autosome, a new " $Y$ " which is homologous with the fused autosomal portion of the new $X$, and the original $\mathbf{Y}(20,39)$.

Carollia (Carollinae) is a classic example of this X-autosome translocation. Fusion with an autosome by one of the arms of the original metacentric $X$ yielded the present subtelocentric $X$ 
and the $\mathrm{XY}_{1} \mathrm{Y}_{2}$ mechanism. The development of Choeroniscus is more difficult to explain. It is the only genus in the subfamily Glossophaginae to have this mechanism of sex chromosomes. The relationship of this karyotype to that of Carollia is not clear. The two genera may not be closely related and could represent parallel developments. Artibeus jamaicensis, lituratus, and toltecus of the subfamily Stenoderminae all have essentially the same karyotype and the $X_{1} Y_{2}$ mechanism. A. turpis differs only by having a metacentric $Y$. This morphology suggests the fusion of $\mathrm{Y}_{1}$ and $\mathrm{Y}_{2}$. Thus turpis may be more advanced chromosomally than the other members of the genus (20).

BAKER (2) has made extensive studies on the chromosomes of phyllostomid bats and has arranged their karyotypes into seven related groups.

\section{a) Pteronotus (Chilonycterinae)}

This genus is in a subfamily which is distinctly primitive (23). Its karyotype is somewhat similar to species in Phyllostomatinae, but there are enough differences to place it in a distinct chromosomal group.

\section{b) Cnocronycteris and Choeroniscus (Glossophaginae), and Carollia (Carollinae)}

This group is characterized by low diploid numbers (16-21) and FN (?24-36), the XX/XY $Y_{1} Y_{2}$ mechanism, and about twice as many metacentric and subtelocentric as acrocentric chromosomes.

\section{c) Leptonycteris and Glossophaga (Glossophaginae), Phyllostomus Trachops, and Macrotus (Phyllostomatinae)}

All of these genera have a high F.N. (50-60), diploid number of 30 or greater, and similar karyotypes lacking telocentric chromosomes, except for Macrotus. Centric fusion of the telocentrics in this genus could produce a karyotype similar to that of the others. The differences in F.N. and diploid number among these genera are important and indicate that significant chromosomal changes have occurred since their derivation from a proposed common ancestor.

\section{d) Anoura (Glossophaginae)}

This genus has a karyotype that is not related to any other in any obvious way.

\section{e) Micronycteris (Phyllostomatinae)}

The large F.N. (68) and unusually large number of subtelocentrics indicate extensive inversions from the karyotype of an ancestral stock. This karyotype is also not clearly related to another genus in this family.

\section{f) Sturniva (Sturnirinae), Arbiteus, Vampyros, Chiroderma, Euchisthenes and Century (Stenoderminae)}

Sturnira, Artibeus, and Vampyrops have identical autosomes. The $\mathrm{XY}_{1} \mathrm{Y}_{2}$ mechanism in Artibeus has been discussed above. Sturnira and Vampyrops have subtelocentric single $\mathrm{Y}$ chromosomes. These may have been derived from a centric fusion of $Y_{1}$ and $Y_{2}$, or the double $Y$ mechanism in Artibeus may have been formed by the centric fission of an original biarmed $Y$ chromosome as present in the first two genera. In either case, Sturnira is closely related to the other genera of Stenoderminae, and Sturnirinae does not represent a separate subfamily.

Enchisthenes has a karyotype similar to that of Sturnira. Centurio and Chiroderma are less closely related to the others in the group and have undergone extensive rearrangements of their chromosomes during species differentiation. 


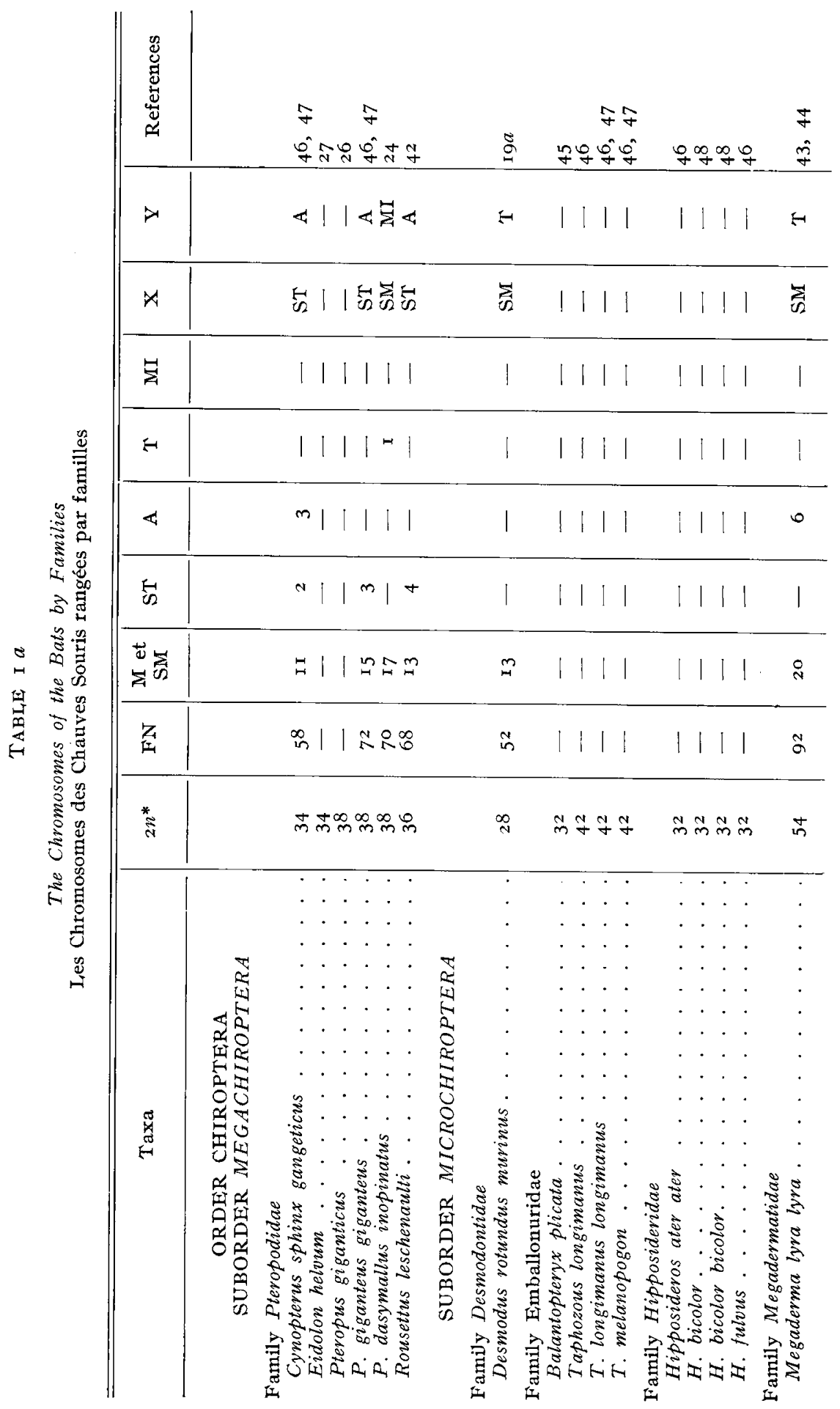




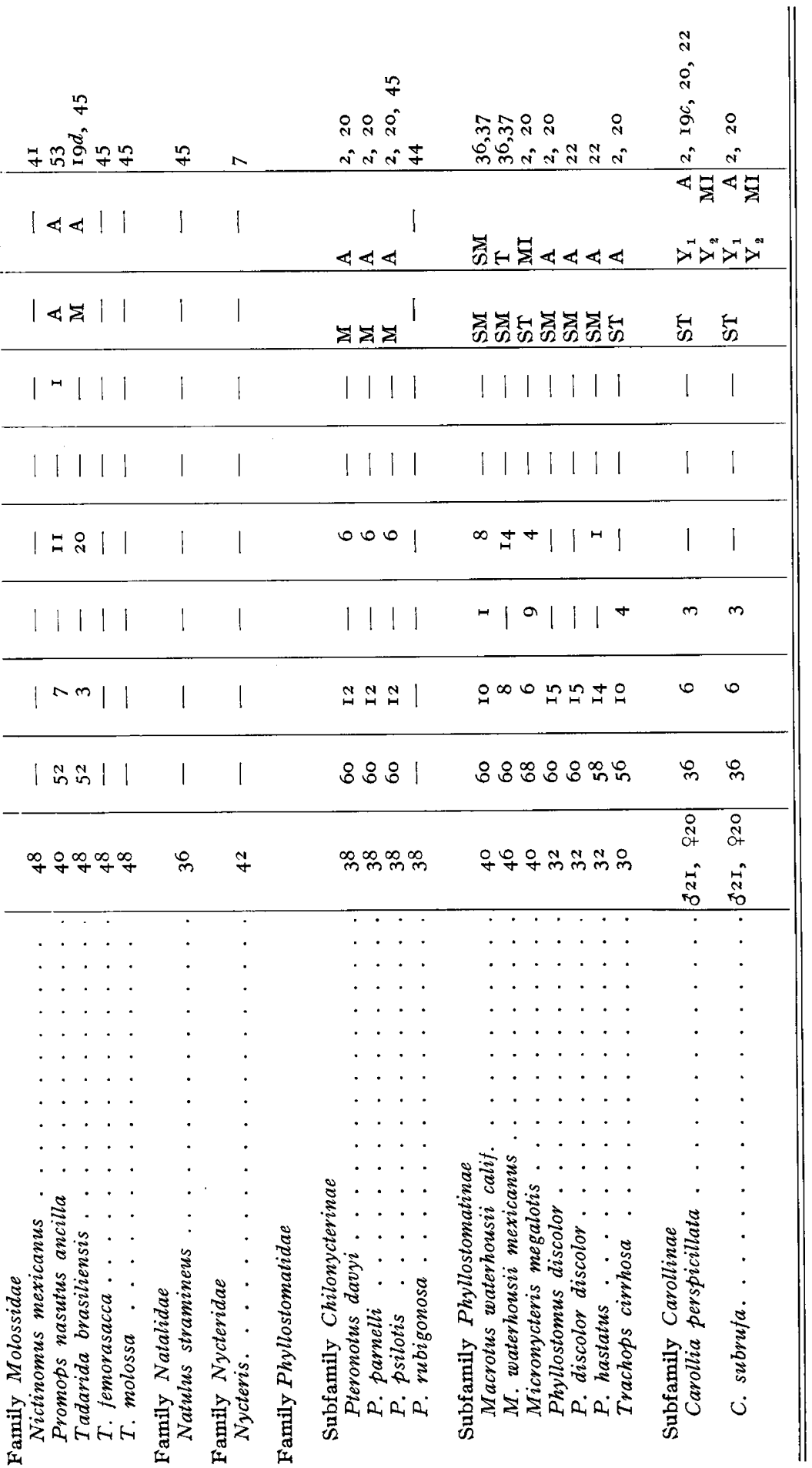


A. R. RUSHTON

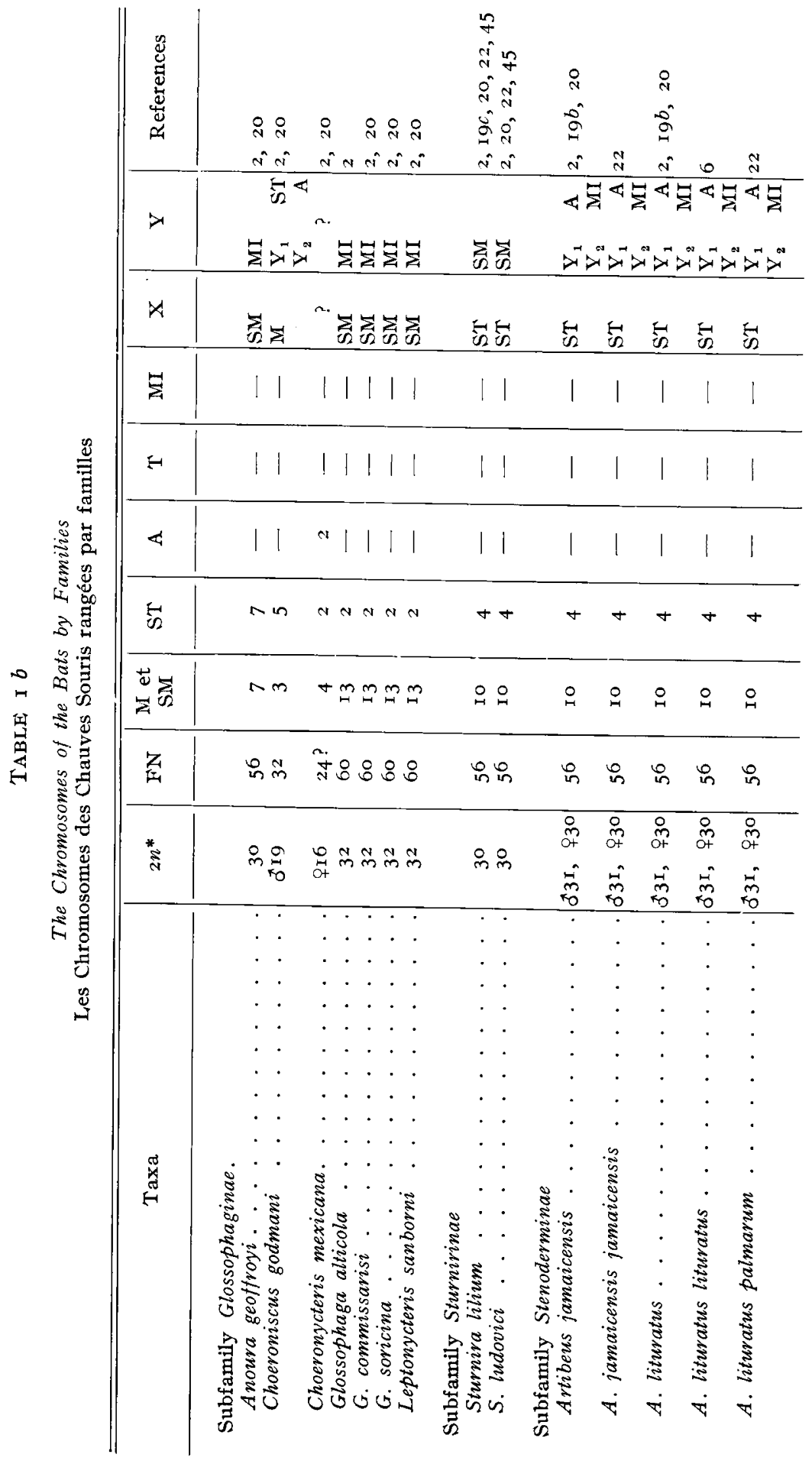




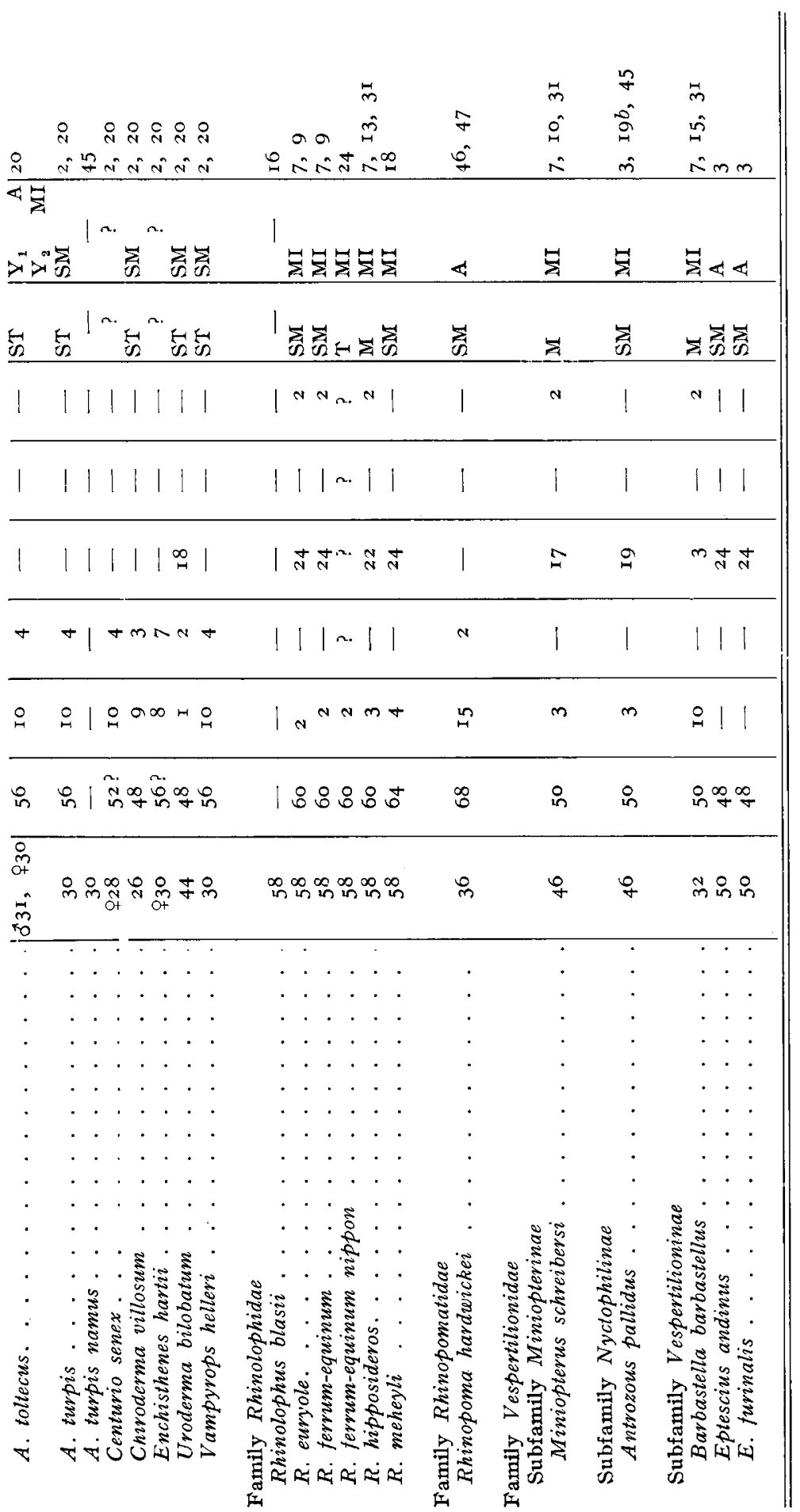




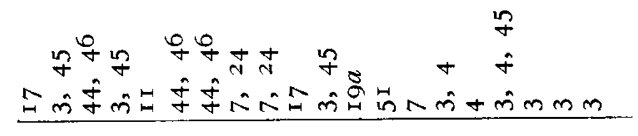

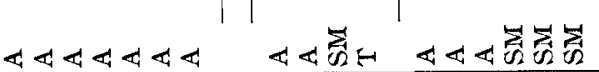

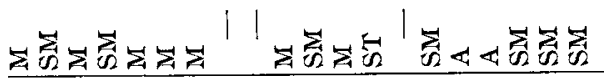

$m|1| \approx|1| 101|1| 1|1| 1 \mid$

$1|1| 1|1| 1|1| N|1| 1|1|$

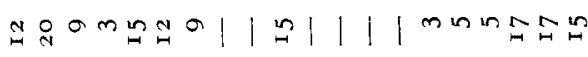

$\left.||^{H}||||||||^{m}||||\right|^{m}$

以

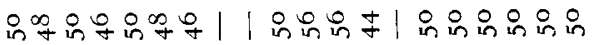

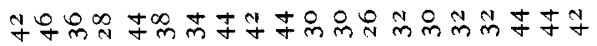
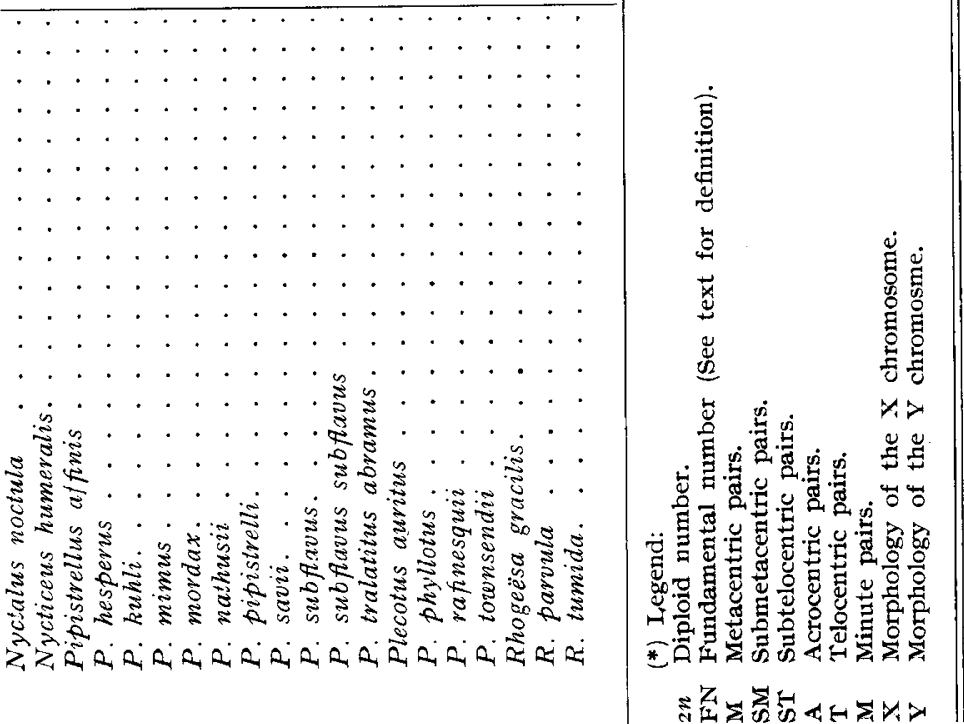

Annales de Génétique et de Sélection animale. - 1970. 


\section{g) Uroderma (Stenoderminae)}

The presence of eighteen acrocentric pairs makes this karyotype unique within the family. Until other species of this genus are karyotyped, it must represent a separate group. The genus may represent a primitive karyotype that has been maintained without gross changes while the rest of the phyllostomid stock continued to evolve chromosomally.

\section{FAMILY DESMODON'TIDAE}

Taxonomically this family is closely related to Phyllostomatidae (23). The karyotype of Desmodus rotundus murinus is the only reported one for this family, but it is superficially similar to those of Centurio and Chiroderma in Stenoderminae. More karyotypes must be reported before any more definitive relationship can be established.

\section{FAMILY RHINOLOPHIDAE}

The karyotypes of Rhinolophus euroyle and ferrum-equinum are essentially identical. $R$. hipposideros has two less chromosomes than these species but the same F.N. The large pair of metacentrics in hipposideros could have been formed by the centric fusion of two pairs of acrocentrics in the ancestor of these species (9). The derivation of meheyli from euryole is more complex, and the relationship cannot be clearly defined on the basis of chromosomes alone.

\section{FAMILY VESPERTILIONIDAE}

This has been the most extensively studied family in the order. Baker and Patrox (3) have reported a large number of karyotypes from this family and have organized their results into four groups based on similar karyotypes. Species reported by other workers fit reasonably well into this tentative schema.

a) Myotis, Rhogeësa, Eptescius, Nyctalus, and Nyctecius (Vespertilioninae), Miniopterus (Miniopterinae), and Antrozous (Nyctophilinae)

This group is characterized by a high diploid number (42-50), stable F.N. (48-50), and a large number of acrocentric chromosomes.

All of the reported North American Myotis have the same karyotype and must have developed from the same line (3). Two European species, M. myotis and capaccinii, differ by having a metacentric $\mathrm{X}$ and an acrocentric $\mathrm{Y}$. A pericentric inversion in each of the sex chromosomes could change one karyotype into the other.

\section{b) Plecotus, Euderma, and Barbastella (Vespertilioninae)}

These three genera are closely related. Barbastella is considered to be the representative of the ancestral karyotype with diploid number of 32 and a submetacentric X. Centric fusions and pericentric inversions could produce Euderma with its subtelocentric $\mathrm{X}$ and autosome pair, and diploid number of 30 . Similar events could have produced the separate species of Plecotus (56).

\section{c) Lasiurus and Pipistrellus (Vespertilioninae)}

The genus Lasiurus presents examples of both intrageneric and intraspecific karyotypic variation. I. borealis, cinerus, ega panamensis, ega xanthinus, and seminolus have the same 
diploid number (28) and F.N. (46) and very similar karyotypes. L. borealis blossevillii and ega argentinus have lower diploid numbers (22-24) and F.N. ten less than the first species. L. ega intermedius and intermedius have diploid numbers (26) and F.N. (40-42) in between these two extremes. $L$. borealis blossevillii is thus cytologically more closely related to ega argentinus than to its general species.

Pipistrellus is a large genus with more than fifty species. More karyotype reports are needed before any meaningful relationships can be defined within this genus.

\section{d) Lasionyctéris (Vespertilioninae)}

The one genus in this group is characterized by low diploid number (20) and F.N. (38). Its karyotype is unlike that of any known vespertilionid bats and awaits future explanation.

Using chromosome numbers and morphology, tentative groupings of genera within several families of the bats have been defined. This approach to taxonomy, based solely on the appearance of the chromosomes, is useful but must not be overextended. The Tobacco Mouse (Mus paschiovinus, $2 n=26$ ) from Switzerland differs from the Common Mouse (Mus musculus, $2 n=40$ ) by seven Robertsonian fusions. There are no known intermediate species, and the two share biochemical gene loci (38). The Indian Muntjac (Muntiacus muntjak) has diploid number 6 in the male and 7 in the female, while closely related species and genera have diploid numbers from 46 to $70(57,58)$.

These results support the contention that certain types of chromosomal rearrangements may play a role in species formation, but that there does seem to be a degree of independence between organic and chromosomal evolution such that changes in the karyotype are not necessarily the cause of speciation $(34,54,55)$. In Chiroptera the karyotype is generally conservative at the generic level. The widespread genera such as Myotis appear to maintain one karyotype despite diverse evolutionary pressures. Anomalous groups such as Lasiurus accentuate the weakness of all such generalities. Before more definitive statements can be made regarding relationships within the family, more karyotypes must be reported. Above all, the chromosomal data must be correlated with traditional taxonomic evidence in order that intrafamilial relationships may be more meaningfully defined. It is hoped that this review will stimulate continued effort to obtain karyotypes of more species of Chiroptera.

\section{ACKNOWLEDGEMENTS}

The author wishes to thank Dr. J. H. Woolpy of the Biology Department of Earlham College and Dr. S. Orwno of the City of Hope Medical Center in Duarte, California for critically reading the early manuscripts of this work.

\section{ABOUT THE AUTHOR}

Alan R. Rushton is in the Biology Department of Earlham College in Richmond, Indiana U.S.A. His work involves teaching techniques of chromosome analysis to siudents and guiding research activities. Current work involves studies on familial inheritance of human chromosome anomalies and the cytogenetics of an inbred population of aggressive rabbits. During the past two summers he has collaborated with Dr. Janet D. Rowley, Argonne Cancer Research Hospital of the University of Chicago, on autoradiography and fluorescence of human sex chromosomes. 


\section{RÉSUMÉ \\ CYTOTAXONOMIE ET ÉVOLUTION CHROMOSOMIQUE \\ DE LA CHAUVE-SOURIS (MAMMALIA-CHIROPTERA)}

Une compilation extensive a fourni le nombre diploïde des chromosomes de 110 espèces de Chauves-Souris. A partir de 87 caryotypes connus, on s'est efforcé d'établir les relations cytologiques existant à l'intérieur des familles suivantes : Pteropodidae, Rhinopomatidae et Vespertilonidae. Pour établir des relations interfamiliales absolument certaines, la connaissance du caryotype de nouvelles espèces est encore nécessaire.

\section{REFERENCES}

I. Allen G. M., I939. Bats, Cambridge, Harvard University Press.

2. BAKER R. J., I967. Karyotypes of bats of the family Phyllostomidae and their taxonomic implications. Swest. Nat., 12, 407-428.

3. Baker R. J. and Patton J. I., 1967. Karyotypes and karyotypic variation in North American vespertilionid bats. J. Mammal., 48, 270-286.

4. Baker R. J. and Mascarello, J. T., r969. Chromosomes of some vespertilionid bats of the genera Lasiurus and Plecotus. Swest. Nat., 14, 249-25I.

5. BecaK M. L., BecaK W. and Rabello M. N., 1966. Cytological evidence of constant tetraploidy in the bisexual South American frog, Odontophrynus americanus. Chromosoma, 19, 188 -I93.

6. BECAK M. L., Batistic R. F., Vizatto $I_{\text {. }}$ D. and BecaK W., I969. Sex determining mechanism $\mathrm{XY}_{1} \mathrm{Y}_{2}$ in Artibeus lituratus lituratus (Chiroptera-Phylostomidae). Experientia, 25, 8I-83.

7. Bovey R., 1949. Les chromosomes des Chiroptères et des Insectivores. Rev. Suisse Zool., 56, 37 I.

8. Brosset A., r966. La Biologie des Chiroptères, Masson, Paris.

9. Capanna E., I968. Some considerations on the evolution of the karyotype of Microchiroptera. Experientia, 24, 624-626.

1o. Capanna E., and Civirelli M. V., r964. Contribato alla conoscenze della cariologia dei rinolofidi (Mammalia-Chiroptera). Caryologia, 17, 36r-37r.

I I. Capanna E. and Crvitelli M. V., 1965. Cariologia e cariometria del minioterro (Mammalia-Chiroptera). Caryologia, 18, 54I-546.

12. Capanna E. and Civitelli M. V., I966. I chromosomi del pipistrello albolimbato. Caryologia, 19, 23 I-240.

13. Capanna E. and Crvitelli M. V., 1967. I chromosomi di Pipistrellus savii. Caryologia, 20, $265-272$.

14. Capanna E., Crvitelli M. V. and Spagnuolo C., r968. Contribato alla cariologia del genere $M$ yotis considerazioni sulla evoluzione del cariotipo dei Vespertilionidae (Mammalia-Chiroptera). Caryologia, 21, 225-240.

15. Capanna E., Contr L. and Derenzis G., r968. I chromosomi di Barbastella barbastellus (MammaliaChiroptera). Caryologia, 21, 137-145.

I6. Dulic B., I967. Comparative study of the chromosomes of the spleen of some European Rhinolophidae (Mammalia-Chiroptera). Bull. Scient. Cons. Acad. RSF Yugosl., 12, 63-65.

I7. Dulic B., Soldatovic B. and RIMSA D., 1967. La formule chromosomique de la Nyctalus noctulus Schreber (Mammalia-Chiroptera). Experientia, 23, 945-946.

I8. DuLIC B. and SoldAtovic B., I969. Les chromosomes de Rhinolophus meheyli Matchie rgoo (Mammalia-Chiroptera). Caryologia, 22, $\mathrm{x}-5$.

19a. Hsu T. C. and Benirschke K., 1967. An Atlas of Mammalian Chromosomes. New York, SpringerVerlag. Volume $\mathrm{I}$.

I9b. Ibid., I968. Volume 2.

I9c. Ibid., x969. Volume 3.

r9d. Ibid., I970. Volume 4.

20. Hsu, T. C., BAKER R. J. and UTOKAJI T., rg68. The multiple sex chromosomes of American leafnosed bats (Chiroptera, Phyllostomidae). Cytogenetics, 7, 27-38.

21. Jepsen, G. I., r966. Early Eocene bat from Wyoming. Science, 154, I333-1339.

22. Kiblisky P., I969. Chromosome patterns of 7 species of leaf-nosed bats of Venezuela (ChiropteraPhyllostomidae). Experientia, 25, I 203-1204.

23. LEEN N. and Novick A., I969. The World of Bats. New York, Holt, Rinehart and Winston.

24. Makino S., 1948. A study of the chromosomes in two species of bats (Chiroptera). Biol. Bull., 94, $275-282$. 
25. Maxino S., I951. An Atlas of the Chromosome Numbers in Animals. Ames, Iowa, Iowa State University Press.

26. MANNA G. K. and TALUkdar M., I965. Somatic chromosome numbers in twenty species of mammals from India. Mammalian Chromosomes Newsletter, ( 17$), 77$.

27. Matthey R., 1962. Les nombres diploides des Mammifères euthériens. I,iste critique. Mammalian Chromosomes Newsletter, (8), 22-23.

28. MATthey R., I 967 . Introduction to the fifth supplement of the list of chromosome numbers by eutherian Mammals. Mammalian Chromosomes Newsletter, 8, (2), 88-9o.

29. Matrhey R., I968. Chromosome numbers of eutherian Mammals-6th Supplement. Mammalian Chromosomes Newsletter, 9, (2), 75-76.

30. MAtThey R., 1969. Chromosome numbers of eutherian mammals-7th Supplement. Mammalian Chromosomes Newsletter, 10, (4), 232-237.

31. Matthey R. and Bovey R., 1948. Ira formule chromosomique chez cinq espèces de Chiroptères. Experientia, 4, 26-27.

32. Mayr E., I963. Animal Species and Evolution. Cambridge, Harvard University Press.

33. Merrel, D. J., 1962. Evolution and Genetics. New York, Holt, Rinehart and Winston.

34. Meylan A., r964. I,e polymorphisme chromosomique de Sorex araneus. Rev. Suisse Zool., 71, 903-983.

35. Muramoto J., Ohno S. and Atkin N. B., 1968. On the diploid state of the fish order Ostariophysi. Chromosoma, 24, 59-66.

36. Nelson-ReEs W. A. and KNIOzEFF A. J., I968. Intraspecific chromosome variations in the bat, Macrotus waterhousii. Mammalian Chromosomes Newsletter, 9, (I), 40.

37. Nelson-Rees W. A., Kniozeff A. J., Baker R. J. and Patton J. L., I968. Intraspecific chromosomal variation in the bat Macrotus waterhousii Gray. J. Mammal., 49, 706-7r2.

38. OHNo S., personal communication.

39. OHno S., 1969. Evolution of sex chromosomes in mammals. An. Rev. Genet., 3, 495-524.

40. OHNo S., Wolf U. and Atkin N. B., I968. Evolution from fish to Mammals by gene duplication. Hereditas, 59, I09-1 87 .

4I. Painter T. S. 1925. A comparative study of the chromosomes of mammals. Amer. Natur., 59, 385 .

42. Pathax S., I966. The chromosomes of Megachiroptera, Rousettus leschenaulti Desmarest. Chromosome Information Service, (7), 5.

43. Pathak S., I968. The karyotype of the Indian false vampire bat, Megaderma lyra lyra. Mammalian Chromosomes Neresletter, 9, (4), 238.

44. Pathak S. and Sharma T., I969. Chromosomes of five species of Indian Vespertilionid bats. Caryologia, 22, 35-46.

45. Patton J. I. and Baker R. J., I966. Somatic chromosomes of 31 species of North American Chiroptera. Mammalian Chromosomes Newsletter, (20), 66-67.

46. Ray-Chaudhuri S. P. and Pathak S., I966. Studies on the chromosomes of bats: List of worked out Indian species of Chiroptera. Mammalian Chromosomes Newsletter, (22), 206.

47. Ray-Chaudhuri S. P., Pathak S. and Sharma T., i968. Chromosomes and affinities of Pteropodidae (Megachiroptera) and Rhinopomatidae (Microchiroptera) in The Nucleus (A. K. SHARMA, ed.).

48. Ray-Chaudhuri S. P., Pathax S. and Sharma T., 1968. Chromosomes of five Indian species of Microchiroptera. J. Mammal. (in press).

49. Robertson W. R. B., I9r6. Chromosome Studies. J. Morphol., 27, I79-33I.

50. Romer A. S., r966. Vertebrate Paleontology, Chicago, tr. University of Chicago Press.

5x. Takayama S., 1959. The chromosomes of a bat: Pipistrellus tralatitus abramus. Jap. J. Genet., 34, I07-110.

52. TJio J. H. and Whang J., 1962. Chromosome preparations of bone marrow cells without prior in vitro culture or in vivo colchicine administration. Stain Technol., 37, 17-2o.

53. WAinberg R. I., I966. Cytctaxonomy of South-American Chiroptera. Arch. Biol., 77, 411-124.

54. White M. J. D., Ig68. Models of Speciation. Science, 159, ro65-107o.

55. White M. J. D., x969. Chromosomal rearrangements and speciation in animals. An. Rev. Genet.,

3, $75-98$.

56. Williams D. F., DRUecker J. D. and Block H. I., I970. The karyotype of Euderma maculatum and comments on the evolution of Plecotine bats. J. Mammal., 51, 602-606.

57. Wurster D. H. and BEnirschke K., 1967. Chromosome studies in some deers, the Springbok, and the Pronghorn, with notes on placentation in deer. Cytologia, 32, 273-285.

58. Wurster D. H. and Benirschke K., r970. Indian muntiac, Muntiacus muntjak, a deer with a low diploid chromosome number. Science, 168, 1364-1366. 